\title{
Korpusonomastinen tutkimus slanginimistä Hesa ja Stadi digitaalisissa diskursseissa
}

\section{Johdanto}

Hesa ja Stadi ovat tunnetuimmat Helsinkiä tarkoittavat slanginimet. Niiden synty ajoittuu yli sadan vuoden taa, jolloin Helsingin (eli Stadin) slangi sai alkunsa. Molempien käyttöön ja käyttämättömyyteen liittyy jaettuja käsityksiä ja normeja siitä, ketkä nimiä käyttävät. Hesa mielletään muualta Helsinkiin muuttaneiden ja muualla Suomessa asuvien käyttämäksi, kun taas Stadia pidetään syntyperäisten helsinkiläisten nimenä. Myös Hesa on alun perin ollut syntyperäisten helsinkiläisten kotikaupungistaan käyttämä nimi, mutta toisen maailmansodan jälkeen käyttötapa on muuttunut. Samalla Stadin leima syntyperäisten ja "aitojen" helsinkiläisten käyttämänä nimenä on vahvistunut. Stadi on vanhastaan tarkoittanut paitsi Helsinkiä ja erityisesti sen keskikaupunkia myös kaupunkia yleisesti. (Paunonen - Paunonen 2000; Ainiala - Lappalainen 2010.)

Slanginimien Hesa ja Stadi käytöllä tai käyttämättömyydellä ilmennetään usein identifioitumista tietynlaiseksi helsinkiläiseksi tai erottautumista tietynlaisesta helsinkiläisyydestä (Ainiala - Lappalainen 2017; Ainiala - Lappalainen 2010). Molempia nimiä käytetään myös osana kaupallista ja institutionaalista nimistöä ja kieltä, mikä osoittaa paitsi itse nimien myös niihin kytkettyjen merkitysten tunnettuutta. Helsinkiläisten yritysten nimissä Stadi on Hesaa jonkin verran tavallisempi, ja kiinnostavaa on, että slangisanastoa yhdistetään vain Stadin sisältäviin nimiin (esim. Stadin Bygga; bygga 'rakennus, rakennustyömaa'). (Ainiala 2013.) Vaikuttaa siltä, että varsinkin Stadin käyttöala osana julkista kielenkäyttöä on kasvanut. Stadin ammattiopisto aloitti toimintansa vuonna 2013, ja Helsingin kaupungilla on lukuisia Stadi-nimen sisältäviä palveluja ja toimintoja (esim. Stadin asunnot, Stadin ikäohjelma). Slangisanastoa on Helsingissä muutoinkin otettu käyttöön virallisessa ja kaupallisessa nimistössä, tällaisia ovat muun muassa kaavanimet Fredikanterassi ja Baana sekä Hertsikan ala-asteen koulu.

Tähänastisissa Hesaa ja Stadia koskevissa sosiolingvistisissä ja -onomastisissa tutkimuksissa aineistona on ollut pääosin haastatteluja sekä kyselylomake- ja 
keskusteluaineistoja. (Ks. Ainiala-Lappalainen 2017; Ainiala-Lappalainen 2010.) Haastateltavat ja muut vastaajat ovat olleet helsinkiläisiä. Nimien kaupallista käyttöä on puolestaan tutkittu tarkastelemalla helsinkiläisten yritysten ja kaupungin palvelujen nimistöä (ks. Ainiala 2013). Tutkimuksissa menetelmät ovat olleet kvalitatiivisia. Tässä tutkimuksessa selvitämme näiden slanginimien käyttöä uudentyyppisen aineiston ja menetelmän avulla ja teemme ennen kaikkea kvantitatiivista tutkimusta laajan korpuksen avulla.

Yhdistämme työssämme korpustutkimuksen ja nimistöntutkimuksen lähtökohtia ja tavoitteita. Tutkimuksemme on korpusavusteista onomastiikkaa eli korpusonomastiikkaa. Sillä tarkoitamme nimistöntutkimuksen alaa, jossa aineistoina käytetään laajoja korpuksia, joiden analyysi perustuu korpustutkimuksen menetelmiin (kuten sanalista-, konkordanssi- ja avainsana-analyysiin) ja joiden tarkastelun kohteena on nimien yleisyys, käyttö tekstikonteksteissa (esim. kollokaatiot ja muut fraseologiset suhteet sekä tilannekontekstit, kuten tekstilajit) sekä alueellinen ja paikallinen variaatio. Menetelmällä pyrimme tuomaan nimistöntutkimukseen uusia näkökulmia sekä rikastamaan korpustutkimuksen ja tässä tutkimuksessa myös diskurssianalyysin kenttää: työmme kolmas kulmakivi on diskurssintutkimus, joka yhdistettynä sähköisiin aineistoihin purkaa jaettuja yhteiskunnassa vallitsevia merkityksiä lähtien liikkeelle kvantitatiivisesta analyysista (tarkemmin luvussa 3). Kysymme, millaisia ovat slanginimiin Hesa ja Stadi liittyvät diskurssiprosodiat Suomi24-keskustelupalstalla. Selvitämme siis, millaista digitaalinen kansalaiskeskustelu näistä sanoista on Suomen vilkkaimmalla keskustelupalstalla.

\section{Nimistöntutkimus ja digitaaliset aineistot}

Nimistöä koskevassa tutkimuksessa varsinaisia tekstikorpuksia on käytetty harvakseltaan eikä suomalaisen nimistön tutkimuksessa juuri ollenkaan. Sähköistä dataa on toki hyödynnetty, mutta hyvin yleistä on, että aineisto on muodostunut erilaisista nimilistoista, joihin voidaan kohdistaa yksinkertaisia hakuja ja annotaatioita. Tällaisia nimilistoja on käytetty sekä henkilön- että paikannimien tutkimuksessa. Suomalaisten viralliset henkilönnimet ovat olleet käytettävissä Väestörekisterikeskuksessa jo vuosikymmeniä, ja tämän aineiston avulla on tutkittu muun muassa nimien suosionvaihtelua ja nimien ja nimityyppien jakautumista (esim. Kiviniemi 2006; Mikkonen - Paikkala 2000). Maamme kattavat paikannimikokoelmat tulivat puolestaan sähköisesti käytettäviksi vuoden 2017 lopussa, kun yli 2 miljoonan paikannimitiedon digitaalinen Nimiarkisto avautui (www.nimiarkisto.fi). Sen avulla voidaan tutkia esimerkiksi nimien ja nimielementtien esiintymistä ja levikkejä. Jo aiemmin oli käytettävissä Maanmittauslaitoksen noin 800000 paikannimeä sisältävä Paikannimirekisteri. Tästä poimittua noin 58000 järvennimen aineistoa on hyödyntänyt Leino (2017), joka on selvittänyt nimeämismalleja ja nimianalogioita käyttäen apunaan todennäköisyyslaskentaa ja tilastollista analyysiä. Vuonna 2019 avattiin Nimisampo (www.nimisampo.fi), joka sisältää sekä Nimiarkiston että Paikannimirekisterin aineistot ja mahdollistaa monipuolisten hakujen ja esimerkiksi kartta-analyysien 
laatimisen (ks. Ikkala ym. 2018). Digitaalisella nimitiedon tallentamisella ja analyysilla on Suomessa siis jo suhteellisen pitkä perinne.

Tutkimustamme varten teimme laajan tietokantahaun aiemman tutkimuksen kartoittamiseksi, ja löysimme erilaisia nimilistoja, digiaineistoja tai varsinaisia tekstikorpuksia aineistonaan käyttäviä tutkimuksia kaikkiaan yli sata. ${ }^{1}$ Nimilistoihin perustuvan analyysin kohteena ovat olleet muun muassa nimien morfofonologiset piirteet, kuten henkilönnimien tavurakenne (Lappe 2002) tai morfologinen ja leksikaalinen analyysi (Pagan 1998), kuvailevien appositioiden ja henkilön- tai yritysnimien kombinaatiot (Bjorge 2003) tai paikannimiin sisältyvät topografisanat (Nurminen 2012).

Myös internet on toiminut sähköisenä datana, koska se on tarjonnut suuren määrän aineistoa tutkittavaksi (erityisesti ennen tietosuojalakeja). Varsinainen suunnitelmallisesti koottu korpusaineisto internet ei kuitenkaan ole. Internet-aineistoja on käytetty tutkimuksissa, joissa on tarkasteltu esimerkiksi Taliban-nimen muotoja amerikkalaisissa ja brittiläisissä lehdissä (Ohlander - Bergh 2004) tai japanilaisten sukunimien eri kirjoitusjärjestelmien mukaisia asuja sosiaalisessa mediassa (Tanaka 2016). Lisäksi on tehty verkkojen käyttäjänimiin kohdistuvaa tutkimusta (esim. Hämäläinen 2019).

Kaunokirjallisuudessa esiintyvien nimien tutkimuksella on vankka sijansa onomastiikassa, ja tälläkin alalla on käytetty sähköisiä aineistoja. Ne ovat muodostuneet tyypillisesti itse kootuista teosten digitaalisista versioista, joista on poimittu nimiä. On esimerkiksi verrattu erikielisissä romaaneissa esiintyvien nimien käyttöä ja funktioita toisiinsa (Dalen-Oskam 2013) tai kirjan erikielisissä käännöksissä esiintyviä nimiä (Tuñón 2013).

Varsinaisia tekstikorpuksia on käytetty vain vähän. Fraseologian alalla on selvitetty esimerkiksi preposition valintaa yhdistysten nimissä (Society of vai Society for) The Bank of English -korpuksesta (Sinclair 2004). British National Corpus on puolestaan ollut aineistona useammassakin tutkimuksessa. On tutkittu esimerkiksi henkilön- ja paikannimien esiintymistä erilaisissa fraseologisissa yksiköissä ja kielirekistereissä (Pierini 2008) tai määräisen artikkelin esiintymistä henkilönnimifraaseissa (Tse 2004). Halverson ja Engene (2010) ovat puolestaan hyödyntäneet norjalaista, noin 150 miljoonan sanan, sanomalehtikorpusta selvittäessään nimien Maastricht ja Schengen esiintymistä sekä metonyymistä käyttöä. America-nimen käyttöä ja kollokaatteja liettualaisessa sanomalehtikorpuksessa on puolestaan selvittänyt Vaičenonienè (2001). Nimien Arab ja Saudi Arabia käyttökonteksteja liettualaisessa sanomalehtikorpuksessa tarkasteleva tutkimus hyödyntää semanttisia preferenssejä ja kollokaatteja (Kamandulytė 2006). Varsinaista korpusonomastista tutkimusta on vielä kaikkiaan siis erittäin vähän, sillä emme löytäneet

1 Tiedonhankinta tehtiin ProQuest-hakukoneen kielitieteen laajempien tietokantojen (MLA ja LLBA), EBSCO-portaalin sekä muiden humanististen alojen tietokantojen avulla. Haussa käytettiin myös opinnäytetietokantoja sekä muitakin kuin englanninkielisiä aineistoja sisältävää Europeana-portaalia. Hakulause laadittiin kahdesta hakusanaryhmästä niin, että tulokseksi tulee tutkimuksia, joiden abstraktista löytyy ainakin yksi onomastinen (esim. onomastics, name studies, proper nouns) ja korpuslingvistinen termi (corpus, electronic data, collocation). Kiitämme tutkimusavustajiamme, Markus Lakaniemeä ja Markéta Sovováta, suuresta avusta työssämme. 
kymmentäkään varsinaisesti korpukseen tai tilastollisiin menetelmiin pohjautuvaa tutkimusta. Korpusonomastiikka-käsitettä tutkimuksissa ei myöskään tuoda esiin.

\section{Menetelmä ja aineistot}

Tutkimus on tehty korpusavusteisen diskurssintutkimuksen (corpus-assisted discourse studies, CADS) menetelmin. Sen lähtökohtana ovat laajat tekstiaineistot, joiden avulla kerätään tutkittavasta ilmiöstä aluksi määrällistä tietoa, ja tutkimuksen edetessä analyysia syvennetään laadulliseen suuntaan. Analyysin alkupisteenä toimivat usein sanalistat ja kollokaatio- tai avainsana-analyysit. CADS yhdistää siten korpusanalyysin kvantitatiivisen ulottuvuuden diskurssintutkimuksen laadullisiin menetelmiin ja hyödyntää molemmille menetelmille tyypillistä nojautumista todellisiin kieliaineistoihin ja ilmiöiden toistuvuuteen. (Ks. Baker 2006; Jantunen 2018.) Menetelmän etuna on muun muassa analyysin perustuminen laajaan tekstimassaan. Tyypillistä on myös, että analyysin kehyksenä on fraseologinen kielikäsitys, jonka mukaan kielenkäyttö perustuu säännönmukaisten ja toistuvien rakenteiden tuottamiseen sen sijaan, että kommunikaatio olisi uniikkia. Kielenkäyttöä ohjaavat kielenkäyttäjien jakamien monisanaisten fraseologisten yksiköiden muistinvaraiset assosiaatiot. (Menetelmästä tarkemmin Partington ym. 2013; Jantunen 2018; kielikäsityksestä mm. Hoey 2005.)

Tämä tutkimus perustuu kollokaatioanalyysiin. Kollokaatiot ovat kahden (tai useamman) sanan muodostamia kiinteitä leksikaalisia syntagmaattisia myötäesiintymiä, jotka ovat toistuvia ja jotka on todennettu tilastollisin menetelmin. (Ks. mm. Sinclair 1991, Jantunen 2004, 15-21.) Kollokaatioanalyysissamme on käytetty tilastollista Mutual Information -testiä, joka korostaa tutkittavan ilmauksen ja kontekstin myötäesiintymän todennäköisyyttä ja tuottaa listauksen pikemmin merkitsevistä sisältösanoista kuin kieliopillisista sanoista (ks. Barnbrook 1996, 95-99)². Analyysissa tarkasteluvälinä on neljä sanaa havaintoyksikön molemmin puoli $(4 \mathrm{~L}-4 \mathrm{R})$, ja kollokaatiksi laskettavan sanan vähimmäisfrekvenssi on 30, mikä pitkälti sulkee pois sen, että kollokaatti on peräisin toistetuista keskusteluvuoroista, ja takaa sen, että kollokaateiksi päätyy vain suhteellisen taajaan esiintyviä sanoja. ${ }^{3}$ Analyysi on tehty Wordsmith Tools -ohjelmalla (Scott 2015) Kielipankin automaattisesti lemmatisoimasta aineistosta, joka latautuu Excel-tiedostona. Tarkasteluun otettiin mukaan 200 tilastollisesti merkitsevintä kollokaattia, mutta koska automaattinen lemmatisointi ei ollut tunnistanut tiettyjä listalle generoituneita sananmuotoja

2 Havainto testin luonteesta on esitetty englannista, mutta aiempi tutkimus suomesta (Jantunen 2004, esim. 76-80, 85-88) ja tästä aineistosta tehdyt testit osoittavat tämän pätevän pitkälti myös suomeen. Lisäksi usein rinnalla käytetty T-testi tuottaa aineistosta merkitsevimmiksi kollokaateiksi enemmänkin frekventtejä kieliopillisia sanoja (esim. stadi: olla, $j a$, ei, se, kun), jotka eivät välttämättä kerro paljon diskurssiprosodioista.

3 Analyysiin otettujen 200 merkitsevimmän kollokaatin MI-arvojen vaihteluväli on 3.43 (asunto, jätkä, kissa, $\mathrm{km}$, törmätä) - 5.24 (ammattiopisto) ja frekvenssien vaihteluväli 30 (bailata, joukkoliikenne, kartta, renki, sali, tyypillinen) - 3204 (kundi), ka. 153 ja Md 67. 
(jotkin kaupungit ja puhekieliset muodot) saman sanan muodoiksi vaan laskenut ne eri lemmoiksi (esim. Tampere, Tampereelta, Tampereelle, ens ja ensi, tääl ja täällä), poistettiin listasta ylimääräiset taivutusmuodot ja tilalle otettiin kollokaatteja niin, että 200 lemmakollokaattia täyttyi. Jotta analyysissa on päästy kiinni Hesaan ja Stadiin liittyviin diskursseihin, on kollokaatit luokiteltu merkityksensä perusteella aineistovetoisesti merkitysryhmiin $^{4}$. Nämä ovat niin sanottuja diskurssiprosodioita eli ilmausten ominaisuuksia esiintyä tietyissä diskursiivisissa konteksteissa (ks. mm. Stubbs 2001, 65-66; Jantunen 2018, 29).

Aineistonamme on Suomi24-keskustelufoorumista koottu Suomi24-korpus (Aller Media Oy 2014), jossa on verkkokeskusteluja eli niin sanottua kansalaiskeskustelua vuosilta 2001-2016. Korpus on saatavissa Kielipankista. Aineistossa on runsaasti aihealueita, kuten harrastukset, nuoret, suhteet ja talous (Meta-Share 2016). Aineistohaut tehtiin Korp-käyttöliittymässä, ja esiintymät kappalekonteksteineen siirrettiin Exceliin, missä aineistosta poistettiin automaattisella duplikaattien poistolla identtiset esiintymät. Näin saatiin tarkasteluun noin 49 ooo Hesa- ja noin 48 ooo Stadi-esiintymää ja noin 3,3 miljoonan saneen tutkimusaineisto ${ }^{5}$.

\section{Tulokset}

Diskurssiprosodioiden selvittämiseksi Hesan ja Stadin 200 merkitsevintä kollokaattia on ryhmitelty aineistoperustaisesti merkitysryhmiin. Aineistosta on pyritty löytämään kontekstissa aktualisoituva yleinen merkitys; kollokaateilla on luonnollisesti useita merkityksiä, mutta ryhmittely on tehty aineistossa tavallisen merkityksen perusteella. Mikäli tavallista merkitystä ei ole pystytty selvästi päättelemään, on kollokaatti ryhmitelty luokkaan muut, kuten on tehty myös kollokaateille, jotka eivät muodosta selvästi jotakin ryhmää. Kuviossa 1 on lueteltu aineistosta erottuvat merkitysryhmät. Kolme suurinta ryhmää ovat: 1) Paikat ja suunnat, kuten kaupungit, kaupunginosat ja rakennukset sekä sanat, jotka eivät määritä tarkasti jotain paikkaa tai tilaa vaan pikemmin sijaintia tai suuntaa. Tähän ryhmään kuuluvia kollokaatteja ovat esimerkiksi ESPOO, BAARI, SEUTU, EDUSTA ja TÄÄLL ̈̈. 2) Liikkuminen ja matkustaminen, johon kuuluvat liikkumista, liikettä, liikennettä ja matkustamista merkitsevät kollokaatit, kuten LÄHTË̈, RUUHKA, DÖs̈̈ ja RISTEILY.

4 Merkitysryhmät ovat syntyneet tutkimusavustajiemme esianalyysissa, ja tämän artikkelin kirjoittajat ovat tarkentaneet ja täsmentäneet luokittelua.

5 Koska kollokaatit lasketaan Korpin tuottamasta aineistosta (eikä koko laajasta Suomi24-korpuksesta, n. 2,6 miljardia sanetta), jossa kontekstina on kappale (usein koko yksittäinen viesti), korostuu MItestissä hakusanan ja kollokaattien yhteisesiintyminen. Tulosta ei voi siten yleistää koko Suomi24aineistoon, vaan se koskee nimenomaan tätä tutkimusta. Vertailu Korpin sanakuvassa tuotettuun MI-testiin kuitenkin paljastaa, että esimerkiksi Korpin 10 merkitsevintä kollokaattia esiintyy myös tutkimusaineiston kollokaattilistalla, joskin eri sijoituksin. Koska tutkimuksessa ei ole ryhmitelty kollokaatteja tilastollisen merkitsevyyden vaan niiden merkityksen perusteella, ei järjestys listalla ole sinänsä merkitsevää.

6 Kollokaatit on merkitty kapiteelein, ja merkintä tarkoittaa lemmaa eli sanat edustavat kaikkia taivutusmuotoja. 
3) Ihmiset, johon lukeutuvat muun muassa ihmistä ja henkilöä tarkoittavat (slangi)sanat, halventavat nimitykset, ammattinimikkeet ja henkilönnimet. Tällaisia ovat esimerkiksi SINKKU, SOMALI, HOMO, HEINÄHATTU ja MIKA.

Aikaa (EILEN, viIKonloppu), tapahtumia, juhlia ja toimintaa (BAIlATA, KonSERTTI, MIELENOSOITUS), asumista (ASUSTAA, KÄMPPÄ), politiikkaa ja yhdistyksiä (KEPU, VIHREÄ) sekä kommunikaatiota (KIITTÄ̈̈, TERVE) merkitseviä kollokaatteja on vähemmän kuin kolmeen yleisimpään ryhmään lukeutuvia sanoja. Määrää (ENITEN, SNADI), urheilua (JOKERI, JOUKKUE) ja opiskelua (OPISKELlA, VALMISTUA) merkitseviä kollokaatteja on vain muutama. Ominaisuutta merkitseviä kollokaatteja on Hesa-nimen yhteydessä erityisen vähän, mutta Stadi-nimen kontekstissa huomattavasti enemmän (esim. AITo, GIMIS). Jotkin kollokaattiryhmistä ovatkin tyypillisiä pikemmin toiselle slanginimelle: Hesalle ovat tyypillisempiä erityisesti merkitysryhmät paikat ja suunnat sekä liikkuminen ja matkustaminen, Stadi puolestaan preferoi ihmisiä, kommunikaatiota ja ominaisuutta tarkoittavia sanoja. Seuraavaksi käsittelemme merkitysryhmiä yksityiskohtaisemmin; tarkastelemme ensin jaettuja diskursseja, minkä jälkeen fokusoimme viiteen Hesaa ja Stadia erottavaan ryhmään.

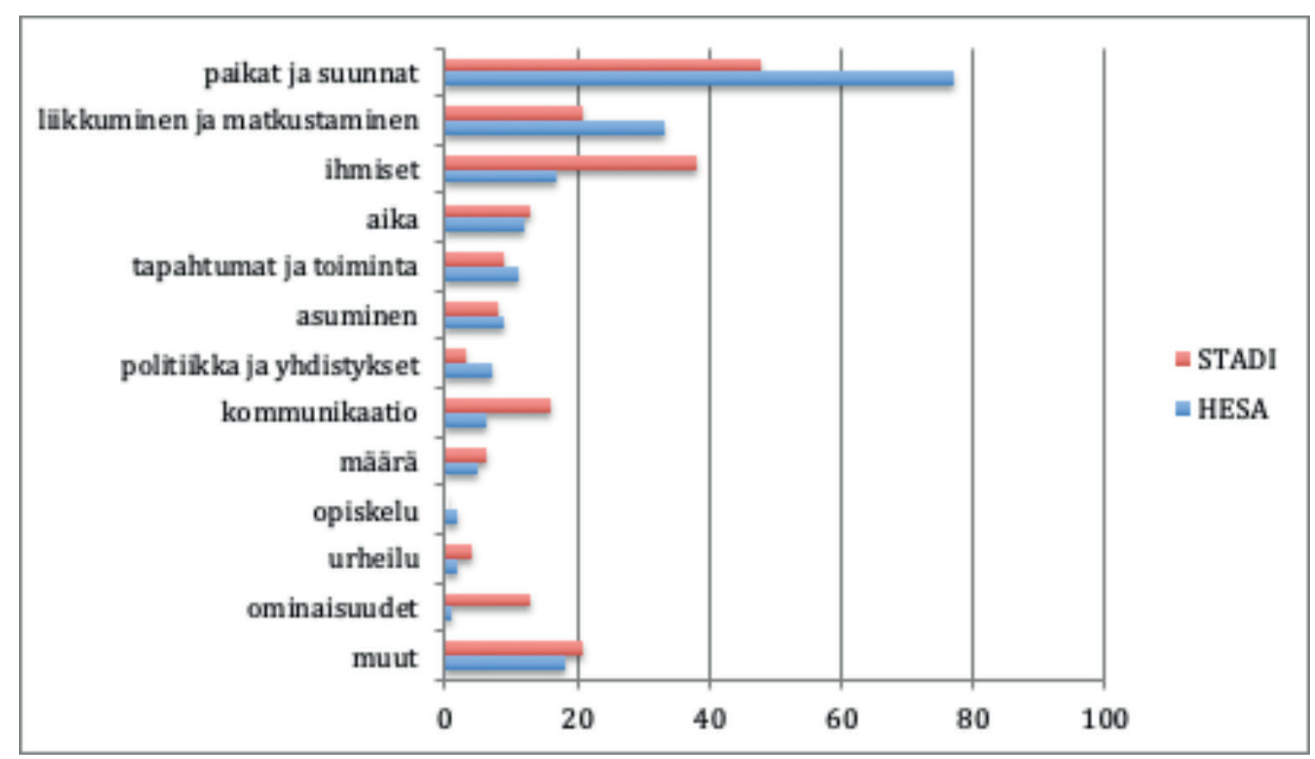

Kuvio 1. Hesan ja Stadin kollokaatit merkitysryhmittäin. 


\subsection{Stadin ja Hesan yhteiset diskurssit}

Slanginimien Hesa ja Stadi merkitysryhmistä osa on siis selvästi yhteisiä, ja tietyt merkitysryhmät ovat tyypillisempiä vain toiselle nimelle. Diskurssiprosodiat, joissa ei ole kovin selvää kvantitatiivista eroa, ovat aika, tapahtumat ja toiminta, asuminen, politiikka ja yhdistykset, urheilu, opiskelu ja määrä; kollokaattien määrissä on prosodioittain eroja vain muutaman kollokaatin verran. Vaikka määrälliset erot ovat pieniä, joitakin laadullisia eroja on.

Ensinnäkin molempia slanginimiä yhdistävät aika-diskurssiprosodian kollokaatit, kuten LAUANTAI, TÄNÄÄN, VIIKONLOPPU, YÖ (esimerkit 1-2), mutta viikonloppuun sijoittuvia viikonpäiviä (PERJANTAI) on enemmän Hesan kollokaattilistalla (esimerkki 3). Stadi puolestaan esiintyy kollokaattien ENÄÄ, JÄLLEEN ja NYKYÄÄN kanssa (esimerkki 4). Nämä kertovat ainakin osittain siitä, että Stadista ja erityisesti Hesasta puhutaan viikonloppuun sijoittuvien tapahtumien tai toimintojen yhteydessä (esimerkit 1, 3; ks. myös 9); lisäksi moni keskustelee myös siitä, että Stadi on muuttunut eikä ole enää samanlainen kuin ennen (esimerkki 4).

(1) Vantaalla on lava "Pavi" mihin muistaakseni on kuljetuskin hesasta viikonloppuisin.

(2) tänään oli stadissakin enää 2 astetta ihan meren rannallakaan

(3) Esim viime perjantaina Pekingin lento lähti Hesasta tunnin myöhässä kun odoteltiin Köpiksestä saapuvia matkustajia.

(4) vittu pelkään kulkee stadis nykyään ku juopot kuseskelee oksentelee sit ne kyselee onks sul huumeita

Toinen yhteinen diskurssi on tapahtumat, juhlat ja toiminta, mutta kollokaatit osoittautuvat kuitenkin melko erilaisiksi, sillä yhteisiä ovat vain KEIKKA, vAPPU ja JUHLIA. Hesaan liittyvät kollokaatit ovat KISA, KONSERTTI, KONVENTTI, MESSU, MIELENOSOITUS ja NÄYTTELY sekä verbikollokaatit JÄRJESTÄ̈̈, JÄRKÄTÄ ja JUHLIA. Stadin kontekstista löytyvät BILEET, JOULU, JUHANNUs ja verbikollokaatit BAILATA, BILETTÄÄ ja DOKATA. Näyttäisi siltä, että Hesan yhteydessä keskustellaan enemmän erilaisista yleisötapahtumista, kuten eri alojen messuista, konserteista ja näyttelyistä ja tapahtumien järjestämisestä (esimerkit 5-7). Stadi puolestaan liittyy juhlimiseen, joko erilaisten pyhien viettoon tai sitten "bailaamiseen" (esimerkit 8-9). Huomattavaa on myös, että Stadin kohdalla kollokaatit ovat toisinaan slangisanoiksi luonnehdittavia ilmauksia, kuten esimerkeissä 8 ja 9 .

(5) Oon ainakin menossa niitten konserttiin, hesaan, joka on muuten ihan kohta!!!!!

(6) X-Trailiin en ole sen enempää tutustunut mitä nyt hesan messuilla kävin istumassa, eikä oikein sytyttänyt.

(7) Meikäläiset potki palloa viime kesänä ainakin Palis-cupissa ja Käpyläcupissa. Kummatkin siis järkätään Hesassa, Käpylän kentillä.

(8) nyt mä lähen tonne stadiin bailaamaan poikaystävän ja sen kamujen kaa. 
(9) Noh, pöllähdä perjantaina Espalle niin siellä näet puolet Stadin teineistä dokaamassa.

Kolmas yhteinen ja vielä suhteellisen yleinenkin diskurssi on asuminen. Yhteisiä kollokaatteja ovat ASUA, ASUSTELlA, MUUTTAa ja YKsıÖ. Vain Hesan yhteydessä esiintyviä ovat ASUNNOTON, ASUSTAA, KAKSIO, KOTOISIN ja MUUTTO, Stadin vuorostaan ASUNTO, KÄMPPÄ, VUOKRA-ASUNTO ja VUOKRAKÄMPPÄ. Vaikka muuttamista koskeva keskustelu voi olla toteavaa ja neutraalia (esimerkki 10), liitetään muuttamiseen usein affektiivisia näkemyksiä joko Helsinkiin muuttamisen puolesta tai sitä vastaan (esimerkit 11-13). Hesa ja Stadi voivat näyttäytyä esimerkiksi kalliina tai paljon mahdollisuuksia tarjoavana asuinpaikkana (esimerkit 11 ja 13).

(10) Juu... mun yks serkku muutti jo 15 vuotiaana hesaan.

(11) Sellaista päivää ei tule koskaan näkymää, että muuttaisin hesan kalliiseen ja stressautuneeseen ihmismassaan.

(12) En määkään tästä stadista tykkää, muuttasin heti maalle, jos vain saisin ILMASEN kämpän tän tilalle...

(13) eikä muualla maassa ole juuri mitään tarjottavana kuin ehkä näin kesällä. Muutan heti stadiin tai pk-seudulle kunhan kykenen.

Pääkaupunkiseudun asuntotilanne keskusteluttaa myös, ja erityisesti Stadin yhteydessä puhutaan vuokra-asumisesta ja sen kalleudesta (esimerkit 14-16). Lisäksi keskustellaan asunnon saamisen edellytyksistä (esimerkki 15) ja vuokra-asumiseen rauhattomuudesta (esimerkki 16).

(14) Stadin kämppien vuokrat ovat vielä tällä hetkellä alemmat kuin ASOvastikkeet, mutta tässäkin näyttäisi olevan muutosta tulossa. Sillä uusien Stadin vuokrakämppien vuokrataso esim. Puksussa ja Viikinmäessä on yllättävän korkea.

(15) Kyllä stadista kämppiä löytyy, jos on töissä ja luottotiedot ok.

(16) Osa asujista on ihan ok mutta toiset on kuin kunnon stadin kämpissä asujia. Rikotaan pihaistutuksia, möykätään rapuissa, tapellaan öisin ja toimitaan pihapoliiseina.

Edellisestä käy ilmi, että kvantitatiivisessa analyysissa yhdistäväksi havaitut diskurssit voivat erota laadullisesti, minkä paljastaa lähempi kollokaattien analyysi. Stadi ja Hesa saavat yhteisissäkin diskursseissa hieman eri painotuksia.

\subsection{Stadia ja Hesaa erottavat diskurssit}

Seuraavaksi käsittelemme diskursseja, jotka ovat tyypillisempiä toiselle tarkasteltavista nimistä. Taulukossa 1 on lueteltu paikkaa ja suuntaa merkitsevät kollokaatit; liikkumista ja matkustamista merkitsevät kollokaatit ovat taulukossa 2. Nämä diskurssiprosodiat ovat tyypillisempiä Hesalle: etenkin paikka ja suunta -diskurssiprosodiaa edustavia 
kollokaatteja on Hesalla selvästi enemmän (77) kuin Stadilla (48). Myös liikkumista ja matkustamista merkitseviä kollokaatteja on Hesalla enemmän (33) kuin Stadilla (21). Kvantitatiivisten erojen lisäksi kollokointi poikkeaa jälleen myös kvalitatiivisesti.

Taulukko 1. Diskurssiprosodia paikat ja suunnat.

\begin{tabular}{|c|c|}
\hline Hesa & Stadi \\
\hline Kaupungit: & Kaupungit: \\
\hline ESPOO, HÄMEENLINNA, JYVÄSKYLÄ, & HESA, VANTAA; \\
\hline KOTKA, KOUVOLA, LAHTI, OULU, PORVOO, & METROPOLI \\
\hline ROVANIEMI, STADI, TAMPERE, TURKU, & \\
\hline VANTAA; & \\
\hline PIETARI, TALLINNA, TUKHOLMA; & \\
\hline METROPOLI, PIKKUKAUPUNKI & \\
\hline Kaupunginosa-alueet ja keskukset: & Kaupungin osa-alueet ja keskukset: \\
\hline ITÄKESKUS, KALLIO, KAMPPI, VUOSAARI; & CITY, KANTAKAUPUNKI \\
\hline KESKUSTA & KESKUSTA, YDIN, YDINKESKUSTA \\
\hline Maakunnat: & Maakunnat: \\
\hline LAPPI & SAVO \\
\hline Kaupat: & Kaupat: \\
\hline AKATEEMINEN, LIIKE, MYYMÄL̈̈ & LIIKE \\
\hline Rakennukset ja tilat: & Rakennukset ja tilat: \\
\hline ASEMA, ASEMATUNNELI, JÄ̈̈HALLI, & AMMATTIOPISTO, JÄÄHALLI, MOSKEIJA, \\
\hline KIRJASTO, KONTTORI, MUSEO, PÄÄKONT- & RAUTATIEASEMA, SALI, STEISSI \\
\hline TORI, RAUTATIEASEMA, YLIOPISTO, YO & \\
\hline Ravintolat: & Ravintolat: \\
\hline BAARI, HOMOBAARI, KASINO, KUPPILA, & BAARI, CHILI, KEBAB, KAPAKKA, KUPPILA, \\
\hline RAVINTOLA & RAFLA, RAVINTOLA, TÄHTI, YÖKERHO \\
\hline Epämääräiset paikat: & Epämääräiset paikat: \\
\hline $\begin{array}{l}\text { ALUE, KULMA, LÄHISTÖ, NURKKA, SEUTU, } \\
\text { YMPÄRISTÖ }\end{array}$ & KULMA, MESTA, SEUTU \\
\hline Sijainnit ja suunnat: & Sijainnit ja suunnat: \\
\hline EDUSTA, KAUKANA, LIEPEILLÄ, LUONA, & EDUSTA, KAUKANA, KESKELLÄ, \\
\hline PUOLESSA, PÄÄSSÄ, SIJAITA, ULKOPUOLELLA; & LÄHEMPI, PÄÄSSÄ, PERÄSSÄ, SIJAITA, \\
\hline ITÄ, LÄNSI, POHJOINEN; & ULKOPUOLELLA; \\
\hline ASTI, KOHTI, PITKIN, PÄIN, SAAKKA, & KOHTI, PITKIN, PÄIN, TAKAS, YMPÄRI; \\
\hline SUUNTA, TAKAS; & LÄHELLÄ, SIELLÄ, TÄÄLL̈̈; \\
\hline LÄHELL̈̈, MISS̈̈, MUUALLA, SIELL̈̈, & LIITTÄÄ \\
\hline TÄÄLLÄ, TUOLLA & \\
\hline Muut paikat: & Muut paikat: \\
\hline $\begin{array}{l}\text { LÄHIÖ, PUISTO, SLUMMI, TORI, } \\
\text { TUPPUKYLÄ }\end{array}$ & LÄHIÖ, SLUMMI, TUPPUKYLÄ \\
\hline
\end{tabular}


Paikan ja suunnan kollokaatit voidaan ryhmitellä edelleen pienempiin ryhmiin taulukon 1 tavoin. Diskurssiprosodiaan lukeutuvat kaupungit, kaupungin osa-alueet ja keskukset sekä maakunnat; kaupat, ravintolat sekä rakennukset ja tilat; paikat, jotka eivät ole tarkkarajaisia sekä sijaintia ja suuntaa ilmaisevat adverbit ja adpositiot. Lisäksi luokittelun ulkopuolelle jää muutamia muita paikkoja.

Kaupunkien ryhmästä erottuu kaupunkien suuri määrä Hesasta keskusteltaessa; Stadilla näitä kollokaatteja on 200:n joukossa vain kolme. Hesan kaupunkikollokaatit ovat sekä suomalaisia että ulkomaisia kaupunkeja, kuten LAHTI ja TUKHOLMA, molempia taas yhdistää METropoli. Slanginimiä Hesa ja Stadi erottaa erityisen selvästi siis se, että Hesasta keskusteltaessa käsitellään myös muita kaupunkeja. Kaupungit mainitaan usein silloin, kun aiheena on matkailu. Hesa nähdään pisteenä, josta matkustetaan (muualta Suomesta) kauemmaksi ympäri maailmaa, kuten esimerkeissä 17-18. Helsinki on matkustusliikenteen solmukohta Suomessa, ja Hesa-nimen motivoi yleensä se, että kirjoittajat ovat Helsingin ulkopuolella asuvia ja sinne matkustavia.

(17) Mistä tiedät matkustatko esim. Venäjälle tai kauemmas, päiväristeily Pietariin Hesasta alle 50.

(18) jollet ota valmismatkaa... niin ota halpalento hesaan ja sieltä laivalla yli tallinnaan ja bussijaamasta pärnuun ,maksaa noin kympin.

Kaupunginosiin ja keskuksiin liittyvä keskustelu eroaa nimien välillä lähinnä laadullisesti. Hesan diskursseihin sisältyy KESKUSTAN ja KAMPIN lisäksi itäisistä kaupunginosista käytävä keskustelu, kuten esimerkissä 19, jossa Helsinkiä katsotaan ulkopuolelta. Myös kantakaupungin läheisistä alueista, kuten Kalliosta, keskustellaan. Esimerkissä 20 keskustelija tuo esiin, että hän ei enää asu kommentointinsa kohteena olevassa Kalliossa. Ei kuitenkaan voida päätellä, asuuko keskustelija yhä Helsingissä.

(19) Kaipaisin Kouvolaan sellaista halpis pihviravintolaa, kuten esim. Itäkeskuksessa Hesassa on tarjolla kakkoskerroksessa.

(20) Kallio on hesan slummi, narkomaanit ja pakolaiskeskukset sijaitsevat kalliossa, hesan väkivaltatilastojen kärjessä, en muuttaisii alueelle enää, ennen siellä asuin, mutta väkivalta ja huumeongelmat pahentuneet vain, ilmankos siellä asuu vain vuokralaisia.

Stadista keskusteltaessa tarkastelukohde on aivan toinen. Keskusteluun nousee usein Helsingin ydinkeskusta ja kantakaupunki. Stadi-nimellä voidaan viitata joko Helsinkiin tai ennen kaikkea sen keskustaan (Ainiala - Lappalainen 2010, 76). Esimerkissä 21 näkyy jälkimmäinen viittauskohde, ja Stadin eli keskustan vastapariksi nousee siinä Itis, jolla viitataan todennäköisesti Itäkeskuksessa sijaitsevaan kauppakeskus Itikseen. Paljon keskustellaan myös siitä, voidaanko Helsinkiä pitää todellisena suurkaupunkina, citynä (esimerkki 22). Stadin ydin ja ydinkeskusta ovat esillä keskusteltaessa palveluista ja asumisen hintatasosta (esimerkit 23-24). 
(21) Ketuttaa et oli ihan hukkareissu lähtee stadiin, ja vielä JULKISILLA, ois kannattunu vaan lähtee omal autolla suoraan itixeen.

(22) Minä sanon teille että Suomen todelliset juntit ovat Stadista. Luulevat asuvansa isossakin cityssä.

(23) Hyvällä lounasravintolallakin olis tilaus Stadin ydinkeskustassa.

(24) Kannattaa huomioida että kolmiot ovat Stadin ytimessäkin halventuneet 7-8\% vuodessa.

Tästä diskurssiprosodiasta nostamme esiin vielä rakennukset ja tilat, ravintolat sekä sijainnit ja suunnat, joista muun muassa ilmansuunnat erottavat nimet toisistaan. JäÄHALLI ja RAUTATIEASEMA ovat yhteisiä kollokaatteja. Helsingin rautatieasema näyttää olevan merkittävä keskustelunaihe, mutta kollokaatit vaihtelevat: Hesan yhteydessä puhutaan ASEMASTa ja ASEMATUNnELISTA, kun taas STEISSi on Stadin kanssa kollokoiva slangisana. STEISSI on Helsingin slangissa yleisesti tunnettu, jo 1950-luvulla käytössä ollut rautatietai linja-autoasemaa ja erityisesti Helsingin rautatieasemaa tarkoittava slangisana (Paunonen - Paunonen 2000). ASEMA liittyy luonnollisesti matkustamisesta keskusteluun, mutta myös rautatieaseman levottomuus ja siellä aikaansa viettävät nousevat esiin (esimerkit 25-26).

(25) Mitä te aijotte tehdä , että kesällä Hesaan uskaltaa tulla ja asemalla likkua junniin tai niitä vaihtaa?

(26) Aika paljon näkyy stadissakin steissillä notkuvan paivällä (työaikaa!!) monikulttuurin edustajia.

Hesan kanssa kollokoivat myös julkiset laitokset, kuten KIRJASTO ja MUSEO sekä yritysten ja pankkien KONTTORI ja PÄÄKONTTORI; keskustelijoita huolettaa esimerkiksi yritysten päätösvallan ja verotulojen keskittyminen Helsinkiin tai pankkien konttorien sulkemispaineet (esimerkit 27-28). Yo ja YLIOPISTO liittyvät muun muassa keskusteluun Helsingin yliopiston opintotarjonnasta ja opiskelumahdollisuuksista sekä vertailuun muiden yliopistojen kanssa (esimerkki 29). Stadin ja AMMATTIOPISTO-sanan kollokointi selittyy pitkälti oppilaitoksen nimellä Stadin ammattiopisto. MOSKEIJA taas liittyy maahanmuuttokeskusteluun, ja vaikka moskeijaa saatetaankin pitää ongelmallisena, toivotetaan se toisinaan myös (ehkä ironisestikin) tervetulleeksi (esimerkki 30). SALI puolestaan kytkeytyy kuntosaliharjoitteluun ja salien kommentoitiin.

(27) Otetaan maakuntien luonnonvaroja ryöstäneet ja niillä rikastuneet pääkonttorit pois Hesasta ja viedään ne maakuntiin eli sinne missä oikeat kansantaloudelle välttämättömän tärkeät varatkin ovat..

(28) Itäkylä,karvala ja hesan konttorit lopetettava ja pääkonttorin pankijohtaja vaihtoon kuten lappajärven op:lla on tapana tehdä kun toimitusjohtaja vaihtuu 
(29) Yliopisto on Vaasassa pieni, mutta toimiva ja opintotarjontaakin on ihan kohtuullisesti - varsinkin jos mukaan otetaan yliopiston rinnalle Åbo Akademin Vaasan yksikkö ja varmaankin sinua kiinnostava Hesan yo:n oikeustieteen koulutus.

(30) Ihanaa että saadaan vihdoin moskeija stadiin!

Taulukko 2. Diskurssiprosodia liikkuminen ja matkustaminen.

\begin{tabular}{|c|c|}
\hline Hesa & Stadi \\
\hline Liikkuminen: & Liikkuminen: \\
\hline HAKEA, KÄVÄISTÄ, KÄYDÄ, KIERRELLÄ. & EKSYÄ, KIERTÄ̈̈, LÄHTEÄ, LIIKKUA, \\
\hline KIERTÄÄ, KULKEA, LÄHTË̈, MARSSIA, & PAINUA, PYÖRIÄ, SAAPUA, SUUNNATA, \\
\hline PYÖRIÄ & TUNKEA, VALUA \\
\hline Liikenne: & Liikenne: \\
\hline AJAA, AJELLA, RUUHKA & AJELLA, JOUKKOLIIKENNE, RUUHKA \\
\hline Liikenneväline: & Liikenneväline: \\
\hline BUSSI, JUNA, LAIVA, SILJA, TAKSI & DÖSÄ, JUNA, PIRSSI, TAKSI \\
\hline Liikenneväylä ja -paikka: & Liikenneväylä ja -paikka: \\
\hline KATU, MOOTTORITIE, MOTARIA, SATAMA, & KATU \\
\hline TERMINAALI, TUNNELI & \\
\hline Matka: & Matka: \\
\hline KILSA, KM & KILSA, KM \\
\hline Matkustaminen: & Matkustaminen: \\
\hline LENTÄÄ, LENTO, LÄHTÖ, MATKA, & MATKUSTAA \\
\hline MATKATA, MATKUSTAA, REISSU, RISTEILY & \\
\hline
\end{tabular}

Edellä kävi ilmi, että Stadin ja etenkin Hesan kanssa kollokoi sanoja, jotka merkitsevät paikkoja ja liittyvät myös liikkumiseen ja matkustamiseen eri paikkoihin tai niiden kautta. Nyt käsiteltävä liikkumisen ja matkustamisen diskurssiprosodia saa siis vahvistusta muistakin diskurssiprosodioista, ja paikka-diskurssiprosodian lisäksi liikkuminen ja matkustaminen liittyvät erityisesti Hesaan. Liikkumisen ja matkustamisen kollokaatit eivät ole tarkkarajaisia, ja niillä on aineistossa useita merkityksiä. Kollokaatit jakautuvat siten, että liikkumista, liikennevälineitä ja liikennettä merkitseviä kollokaatteja on suunnilleen saman verran, mutta väyliä ja yleensä liikkumista tarkoittavia on Stadilla enemmän.

Stadin EKsYÄ voi viitata muun muassa siihen, että joku tulee kaupunkiin (eksyy Stadiin) tai liikkuu siellä ( $k$ un lande eksyy Stadiin ajelemaan). LIIKKUA puolestaan motivoituu usein autoilua koskevasta keskustelusta (Joka metri mikä perheen kanssa stadissa liikutaan, se tehdään autolla), mutta sen merkitys voi olla myös eksistentiaalinen (Stadissa liikkuu raha). PAINUA, SAAPUA, TUNKEA ja VALUA korostavat Stadissa asuvan näkökulmaa: joidenkuiden pitäisi lähteä kaupungista pois (Painu hlvettiin Stadista vtun maalaistollo) 
tai omaan kaupunkiin tulee ei-toivottuja (peräseinäjokisia ja kaltaisiaan on tunkemassa Stadiin vuosittain tuhansia) tai odotettua (Fabulous thunderbirds saapuu Stadiin). suUNNATA tarkoittaa joko Stadiin tulemista tai Stadissa johonkin paikkaan menemistä. Liikkumisen kollokaatit ovat siis sidoksissa myös muuttoliikkeestä keskusteluun, ja Stadi-nimen yhteydessä näkökulma on Helsingissä asuvan, joka pitää ilmiötä usein ongelmallisena, mikä voi näkyä alatyylisenäkin kielenkäyttönä.

Sen lisäksi että Hesan kollokaateista HAKEA tarkoittaa oppilaitokseen tai töihin pyrkimistä (en hakenut Hesaan vaan Turkuun), se on usein myös jonkin asian noutamista Hesasta (tänään lennän Hesaan hakemaan auton). Hesassa oleilu näyttäytyy myös lyhytaikaisena: esimerkiksi verbit HAKEA, KÄVÄIsTÄ ja KÄYDÄ (esimerkki 31) kertovat pistäytymisestä matkan kohteessa. Myös KIERrELlä liittyy Hesaan matkustamiseen (esimerkki 32) mutta myös jonkin asian etsimiseen (oon kierrelyt ympäri hesaa etsiskelemäs). KULKEA liittyy usein joukkoliikenteeseen tai kaduilla ja kaupungissa kulkemiseen ja liikkumiseen (esimerkki 33), MARssi taas mielenosoituksiin (esimerkki 34).

(31) Must on ihanaa, kun saa päähänpiston pakata laukut ja käväistä Hesassa.

(32) no mä aattelin eka mennä vaik hesaan iltapäivällä kiertelee ja kaartelee - -

(33) Kyllä Hesan ratikka kulkee kuin täi tervassa

(34) Meitä oli ainakin 1300 ihmistä Hesassa marssilla iloisella mielellä!

Liikennevälinekollokaatit eroavat siten, että Hesan BUssı saa Stadin yhteydessä vastineeksi slangisanan Dösä (esimerkki 35), samoin kuin TAKSI nimityksen PIRSSI (joukkoliikennevälineiden slanginimityksistä ks. Neuvonen 2016). Hesan LAIVA, RISTEILY ja sILJA sekä LENTÄÄ ja LENTO ovat esimerkkejä sen monista matkustamista merkitsevistä kollokaateista. Yleisemmin matkustamista tarkoittavat LÄHTÖ, MATKA, MATKATA ja REISsU sekä MATKUSTAA, joka on ainoa yhteinen matkustamisen kollokaatti. Myös Hesan liikenneväyliin ja -paikkoihin luokitelluissa kollokaateissa näkyy laivamatkustaminen (SATAMA, TERMINAALI) sekä myös tieliikenne (MOоTTORITIE, MOTARI ja TUNNELI). Kaikkiaan Hesaan näyttää liittyvän sinne matkustaminen ja toisaalta myös matkustaminen kaupungista pois (esimerkki 35), usein eksplisiittisesti mainiten myös se, onko matkustettu lentäen tai laivalla (esimerkit 36-37).

（35） Vika dösä lähtee 22.35 stadista että silleen...

(36) Aika harvoin Siljalle Hesasta Tukholmaan risteilylle pääsee 0-25 eurolla.

(37) - - jos hesast oisin lentäny niin olisi ollut Ruotsissa välilasku.

Seuraavaksi käsittelemme Stadille tyypillisiä kollokaattiryhmiä (taulukko 3). Ensinnäkin ihmisiä merkitsevät kollokaatit ovat selvästi tyypillisempiä Stadille (39) kuin Hesalle (18). Huomattavaa on, että Stadin kollokaateissa slanginimityksiä on peräti reilu kolmannes (14). Näitä ovat muun muassa FRIIDU, JÄBä, KUNDI, STARBU ja LANDEPAUKKU. 
Taulukko 3. Diskurssiprosodia ihmiset.

\begin{tabular}{|l|l|}
\hline Hesa & Stadi \\
\hline Persoonapronomini: & \\
MäÄ & \\
Ammattinimikkeet: & Ammattinimikkeet: \\
BUSSIKUSKI & BUSSIKUSKI, RENKI \\
Kategorianimitykset: & Kategorianimitykset, erisnimet: \\
HOMO, KERJÄLÄINEN, LESBO, LUUSERI, & HILDA-RANE, HOMO, JUSSI, KUNINGAS, \\
PELLE, PUMMI, SINKKU, SOMALI & MAMU, MIKA, PELLE, SINKKU, TYTTÖ, \\
& VAPAAMUURARI \\
Maalaiset: & Maalaiset: \\
JUNTTI, MAALAINEN, SAVOLAINEN & HEINÄHATTU, JUNTTI, LANDEPAUKKU, \\
Politiikkaan liittyvät: & MAALAINEN, SAVOLAINEN \\
EHDOKAS, JÄSEN, KANNATTAJA & Politiikkaan liittyvät: \\
& ASEVELISOSIALISTI, DEMARI, EHDOKAS, \\
Slangi: & PÄ̈̈TTÄJÄ \\
KUNDI & Slangi: \\
& DUUNARI, FRIIDU, GIMMA, HURRI, JANNU, \\
& JÄBÄ, JÄTKÄ, KINGI, KUNDI, PUMMI, \\
\hline
\end{tabular}

Slangisana ja Stadi muodostavat usein hyvin kiteytyneen ilmauksen, kuten esimerkiksi Stadin kundi, Stadin friidu ja Stadin gimma (esimerkit 38-39). Hesan kollokaateissa on puolestaan vain yksi slanginimitys, joka on KUNDI. KINGI ja sen yleiskielinen vastine KUNINGAS liittyvät Stadin kohdalla usein vastakkainasetteluun muun Suomen kanssa (esimerkki 40) ja lisäksi urheiludiskursseissa pelijoukkueiden vertailuun (esimerkki 41).

(38) Stadin kundit ja gimmat ei oo dorkii.

(39) siis kaikki stadin friidut on aivottomia kanapäitä.

(40) Turun pelleille riittää plastic prinsessi. Me stadin kingit nautitaan porauslautasta.

(41) Nää on IHAN eri pelit ku runkosarjassa, on niin moneen kertaan nähty, stadin kingit antaa porkkanapöksyille kyytiä

Myös maalaisia merkitsevät kollokaatit MAALAINEN, SAVOLAINEN sekä pejoratiivisiksikin luonnehdittavat LANDEPAUKKU, JUNTTI ja HEINÄHATTU (esimerkit 42-43) nousevat esiin Stadin yhteydessä, joskin ensin mainitut ovat myös Hesan kollokaatteja. Tyypillisesti tällaisten ilmausten avulla tehdään vastakkainasetteluja Helsingin ja muun Suomen kanssa. Esimerkissä 45 hyödynnetään myös Hesaan ja Stadiin kytkettyjä identiteettimerkityksiä (Ainiala - Lappalainen 2010, 80-91, 97-101): Hesa koetaan ei-syntyperäisille kuuluvaksi 
ilmaukseksi ja stadilaisuus ominaisuudeksi, jonka tavoittelu voidaan nähdä kummastuttavana (ja samalla ehkä pilkattavana). Esimerkistä nähdään myös se, että joskus samassa kommentissa voi esiintyä sekä Hesa että Stadi.

(42) luuseri savolainen, oletko muuttanut oiken stadiin

(43) Ei heinähattujen tarvii Stadiin tulle mitään neuvomaan.

(44) Kukaan maalainen ei halua Hesaan. Joidenkin on ollut pakko muuttaa työn perässä.

(45) On se kumma kun SAVOLAINEN muuttaa HESAAN, siitä tulee HESAN STADILAISIN STADILAINEN!

Stadille ovat tavallisia myös henkilönnimet, kuten Hilda-RANE, Jussi ja MikA. Näistä HildA-RANE on yhden palstan aktiivisen keskustelijan nimimerkki, josta myös keskustellaan usein (esimerkki 46). Hänet tunnetaan myös Stadin starbuna (starbu 'mies', 'vanha mies', 'vanha nainen'). Myös nimimerkki Mika Stadista on palstan ahkera keskustelija, jota myös laajalti puhutellaan ja johon viitataan (esimerkki 47). Jussi puolestaan viittaa usein johonkin julkisuuden henkilöön (esimerkki 48), tai sitä voidaan käyttää appellatiivisesti viittaamassa etenkin "maajussiin" eli maanviljelijään (esimerkki 49). Joskus Jussı tarkoittaa myös juhannusta, mutta silloin se ei kuulu ihmistä merkitsevään diskurssiprosodiaan vaan tapahtumiin, juhliin ja toimintaan.

(46) Stadin starbu eli Hilda-Ranehan se oli tullut taas tutkimusmatkalle Aurinkolahteen, kotoaan kalliosta

(47) Näkemykseesi näyn tulkinnasta yhtyen, vähäinen veli Mika Stadista

(48) Persuista pääsevät Stadissa tohtori Jussi Halla-aho NUMERO 127 SIIS HELSINGISSÄ

(49) Osta sinäkin Stadin Jussi maatila , niin pääset nauttimaan noista tukirahoista!

Yhteisiä ihmistä merkitseviä kollokaatteja Stadille ja Hesalle ovat SINKKU, HOMO, PELLE ja BUSSIKUSKI. Nimien käyttö voi näiden yhteydessä olla liki identtistä. Keskustelija saattaa tuoda esiin sen, missä hän asuu (esimerkki 50) tai missä tietyn ryhmän ihmiset asuvat tällainen keskustelu koskee tyypillisesti seksuaalivähemmistöjä (esimerkki 51). Esimerkissä 52 sekä номо että LESво esiintyivät yhdessä Stadin kanssa. Kuitenkin näistä vain номо on molemmille nimille yhteinen yleinen kollokaatti, ja LESBO kollokoi vain Hesan kanssa. Voidaan myös asettua tarkastelemaan Helsinkiä ulkoapäin, kuten esimerkissä 53 adverbin siellä avulla. PELlen kohdalla näkökulma on liki aina ulkopuolinen: Hesan tai Stadin pellejä tarkastellaan tai puhutellaan Helsingin ulkopuolelta ja usein halventavasti (esimerkki 54). Pelkästään Hesalle tyypillinen kollokaatti on somaLI (esimerkit 55-56), mutta aina ei tuoda eksplisiittisesti ilmi, puhutaanko omasta kotikaupungista.

(50) Asun hesassa, olen yksin, sinkku ja en ryypiskele. 
(51) Palstan vasuripaskat ovat kaikki homoja hesasta

(52) Suurin osa Suomen homoista ja lesboista asuu Stadissa

(53) Ei se suomenkielentaito paljon auta kun ei ne bussikuskit siellä hesassa sano edes päivää.

(54) Lappi ja Lapin asukkaat kyllä pärjäävät omillaan, hesan pellejen vastaväitteistä huolimatta ! Tuolla konstilla välttyisimme sponsoroimasta hesan pellejen ooppera ja teatteri lippujakin kokonaan!

(55) somalit ovat vieneet Hesan asunnot

(56) En tiiä mistä nuo somalit on tulleet Hesan rautatieasemalla

Hesan tavallisin ihmistä merkitsevä kollokaatti on yksikön ensimmäisen persoonan pronomini мä̈̈. Stadilla ei yksikään persoonapronomini nouse esiin. Mää-muoto mielletään usein eri variantiksi kuin pääkaupunkiseudun kieleen kuuluva mä (Lappalainen 2006, 254-255). Sen voi katsoa kytkeytyvän oman identiteetin esittelyyn (vrt. Raevaara 2015, 189-199), ja tässä kontekstissa tuodaan esiin identiteettiä "hesalaisena", ei syntyperäisenä helsinkiläisenä. Esimerkissä 57 tätä identiteettiä vahvistetaan vielä puhuttelemalla lukijaa sää-pronominilla.

(57) Määkin asun hesas, haluisit sää seksiseuraa kans.?

Taulukko 4. Diskurssiprosodia kommunikaatio.

\begin{tabular}{|l|l|}
\hline Hesa & Stadi \\
\hline Kommunikaatio ja kielimuodot: & Kommunikaatio ja kielimuodot: \\
KUTSUA, SLANGI; & BAMLAA, KIITTÄÄ, KIK, KUTSUA, LUVATA, \\
& MURRE, NAURAA, SLANGI, TOIVOMUS, \\
& VÄÄNTÄÄ, VIHJE; \\
Interjektiot: & Interjektiot: \\
JEP, KATO, MOI, TERVETULOA & JEP, JUU, TERV, TERVE, TERVETULOA \\
\hline
\end{tabular}

Kommunikaation kollokaatit (taulukko 4) ovat tyypillisiä Stadille (16), eikä niitä esiinny Hesan kohdalla likikään yhtä usein (6). Molemmille yhteisiä ovat KUTSUA, SLANGI, JEP ja TERVETUlOA. KUTSUA on tavallinen, kun keskustellaan kielimuodoista ja esimerkiksi siitä, millä tavoin Helsinkiä tai jotakin muuta kohdetta kutsutaan (esimerkit 58-59). SLANGI esiintyy usein kiteytyneesti muodossa Stadin slangi, ja tällöin voidaan esittää vahvojakin käsityksiä siitä, millaista slangi on tai mitkä ilmaukset siihen kuuluvat tai eivät kuulu (esimerkki 6o). Esimerkissä 61 mainitaan tsadin slangi. Tsadi on Stadista muodostettu ilmaus, jonka avulla ilmennetään kontrastia Stadiin ja tuodaan esiin myös Stadiin kytkettyjä affekteja (Ainiala - Lappalainen 2010, 90-91). Vastaavasti Hesan slangi mainitaan diskursseissa, joissa esitetään, millaista kieltä slangi on (esimerkki 62). 
(58) pennut kutsuu miksi haluaa, ainakin varttuneemmat kutsuu stadiksi ja hesaksi, landeista, aivan sama millä kutsuvat.

(59) Sit oli stadis myös linja-autoasema, bussiasema busa-asema, miten sitä vaan haluttiin kutsua.

(60) Vekslailee ei kuulu stadin slangiin ja busseil on stadissa DÖSÄ.

(61) Yritätkö olla olevinasi stadin slangin osaaja? Tulos näyttää Stadissa koskaan käymättömän tsadin slangilta.

(62) sekstaaminen, on Hesan slangia ja tarkoittaa suutelemista, se EI siis tarkoita seksin harjoittamista!

TERVETUlOA esiintyy sekä Stadin että Hesan kollokaattina, usein yhteyksissä, joissa toivotetaan keskustelija tervetulleeksi tänne Helsinkiin (esimerkit 63-64) tai muulla tavoin "meidän" kaupunkiimme (esimerkki 65). Muista interjektioista JEP on molemmille yhteinen (esimerkki 66) kun taas KATo (esimerkki 67) kollokoi vain Hesan kanssa. Näitä käytetään, kun osoitetaan hyväksyntää muiden keskustelijoiden kommenteille tai tuodaan esiin eroavia näkemyksiä.

(63) Tervetuloa katsomaan tänne Stadiin missä somalijätkät vetää bisseä joka puolella.

(64) Tervetuloa vierailulle tänne hesaan... täällä nimittäin pannaa ja lujaa , sekä miehet ja naiset !!!!

(65) Parahin Billy. Tervetuloa maamme pääkaupunkiin Stadiin

(66) jep jep , aivan kuin minä . Joskus harvoin kun hesaan pääsee porukalla ja vinkuu että saisi mennä sinne ja sinne niin muu jengi sanoo että ei jaksa --

(67) kato .. se hesa on niin suuri paikka et se halus tietää missä missä paikassa .. asut .. ja sit se vois ehkä selventää mullekkin

Vain Stadille kuuluvia ovat BAmLAA, KIITTÄ̈̈, MURRE, NAURAA, TOIVOMUs, VÄÄNTä̈̈ ja JUU. Näistä slangiasuinen bamlaa-verbi ('puhua'; Paunonen-Paunonen 2000) esiintyy usein keskusteluissa, joissa fokuksessa on slangi ja sen puhuminen. Huomattavan usein kommentit on kirjoitettu joko kokonaan tai suurelta osin slangiksi (esimerkit 68-69), ja joskus Stadi esiintyy kielimuodon (Stadin slangi) merkityksessä, kuten esimerkissä 70. MURRE puolestaan on kollokaatti, jolla tehdään eroa helsinkiläisen kielimuodon ja muiden Suomen kielimuotojen välillä. Samalla voidaan korostaa, että Helsingissä ei puhuta murretta, kuten esimerkissä 71. VÄÄNTÄÄ kytkeytyy usein jonkin kielimuodon, tyypillisesti juuri slangin, "väärin" puhumiseen, kuten esimerkissä 72.

(68) Snyygisti gliffa idis. Kaikki föliin nyt, ruvetaan bamlaan stadin slangii.

(69) Mä bonjaan mitä sä skrivaat, bamlaan slangii, oon födannu Stadis, tarkemmin Bärtsil ja Flemarin alkupääs, Karhiksen vieres.

(70) Stadiks saa bamlaa. 
(71) Moukurapäät ei snaijaa, et stadin kieli ei o murre joka valitettavasti katoaa näiden ja muiden mamujen takia.

(72) Nyt repesin viimeistään. Kun Keravalla asuva savolainen vääntää stadin slangia, niin eipä voi olla juuri huvittavampaa ilmiötä.

Taulukko 5. Diskurssiprosodia ominaisuudet.

\begin{tabular}{|l|l|}
\hline \multicolumn{1}{|c|}{ Hesa } & \multicolumn{1}{c|}{ Stadi } \\
\hline YKKÖNEN & AITO, GIMIS, KAKKONEN, KOMEA, NASTA, \\
& NUORI, PALJASJALKAINEN, PARAS, RAKAS, \\
& SUOSITTU, SYNTINEN, TYYPILLINEN, \\
& VARAKAS, YKKÖNEN \\
\hline
\end{tabular}

Erilaiset ominaisuuksien kollokaatit ovat selvästi tyypillisempiä Stadille (13) kuin Hesalle (1) (taulukko 5). Molemmille yhteinen on YккÖNEN. Sekä Stadin että Hesan kohdalla YKKÖNEN esiintyy keskusteluissa, joissa tuodaan esiin kaupungin paremmuus suhteessa muihin (esimerkit 73-74). ҮкKÖNEN on tavallinen myös urheiluun liittyvissä keskusteluissa. Esimerkissä 75 nostetaan esiin Stadin ja Hesan ero suhteessa erilaisiin helsinkiläisidentiteetteihin (vrt. Ainiala - Lappalainen 2010). Jääkiekkojoukkue HIFK on myös omassa mainonnassaan vahvasti korostanut tätä erontekoa ${ }^{7}$. ҮKкÖNEN on käytössä myös silloin, kun puhutaan liikenteestä ja tarkoitetaan Kehä ykköstä.

(73) Stadi on mulle aina ykkönen! :D

(74) Turussa on kyl muutaman kerran järjestetty ihan hyvät Ravet, mut muuten Hesa on kyl ihan ykkönen!

(75) HIFK on vieläkin ykkönen Stadissa ja tulee aina olemaan. Hesassa se on Jokerit. Helsingin herruus katotaan sitte joskus keväällä.

Stadille kuuluvia kollokaatteja ovat puolestaan muun muassa AITO, GIMIS, NASTA, NUORI, PALJASJALKAINEN, PARAS ja TYYPILLINEN. Näistä varsinkin AITO ja PALJASJALKAINEN liittyvät usein, jopa yhdessä, diskursseihin, joissa tuodaan esiin Helsingille ja helsinkiläisyydelle ("stadilaisuudelle") kuuluviksi hahmotettuja ilmiöitä ja ominaisuuksia (esimerkki 76). AITo kytkeytyy myös osaksi kiteytynyttä ilmausta aito stadin gimma, kuten esimerkissä 77, ja tällaisissa voi jälkimmäisenä osana olla myös kundi tai friidu. GIMIs ('kiva', 'hyvä; Paunonen - Paunonen 2000) taas esiintyy yleensä osana laulun sanoistakin ${ }^{8}$ tunnettua ilmausta Niin gimis on Stadi tai sen muunnosta (esimerkit 79-80).

(76) No aito paljasjalkainen stadilainen sanoo, että stadi on stadi

7 Ks. esim. https://hifk.fi/battrefolk/, https://www.facebook.com/pg/IFK-tulee-Stadista-Jokerit-Hesasta-166579010157268/posts/

8 Ks. esim. https://www.helsinginlaulu.fi/blogi/?k=Lauluja+Helsingist\%C $3 \% \mathrm{~A}_{4}+-+$ stadi+sjungaa 
(77) Soinilta puuttuu Helsingissä oikea, aito stadin gimma joukoistaan.

(78) Olet väärässä en ole savosta niinkuin itse olet vaan olen stadista jo kolmatta sukupolvea eli paljasjalkainen stadin stara.

(79) Niin gimis on Stadi

(80) Stadi on niin gimis.

TYYPILLINEN kuuluu tavallisesti diskursseihin, joissa esitetään, millainen on tyypillinen helsinkiläinen tai Helsingissä asuva (esimerkit 81-82).

(81) Hänhän on kuin tyypillinen stadin hurri tänäkin päivänä.

(82) Tyypillinen vihervasuri nuori stadissa elää sossulla.

Kaikkiaan ominaisuuksia koskevissa diskurssiprosodioissa nostetaan esiin aiemmastakin tutkimuksesta (esim. Ainiala - Lappalainen 2010) tuttuja Stadiin liitettyjä merkityksiä aitoudesta ja myös paremmuudesta suhteesta muihin. Vertailtavina saattavat olla muut helsinkiläiset, joita ei pidetä "aitoina stadilaisina", tai muut suomalaiset.

\section{Pohdinta}

Aiempi Helsinkiä tarkoittavien slanginimien tutkimus on ollut ensisijaisesti laadullista, ja kielenoppaina ovat olleet helsinkiläiset asukkaat. Tässä tutkimuksessa olemme esitelleet uuden tutkimusalan, korpusavusteisen onomastiikan, jossa analyysi perustuu korpustutkimuksen menetelmiin, nyt erityisesti kollokaatioanalyysiin, ja sen avulla tehtyyn korpusavusteiseen diskurssintutkimukseen. Analysoimalla laajaa Suomi24-korpusta olemme saaneet esiin Hesalle ja Stadille tyypilliset diskurssiprosodiat.

Diskurssiprosodioiden vertailu tuo esiin ja vahvistaa jo aiemmassa tutkimuksessa esitettyjä tuloksia: Stadi kytkeytyy usein diskursseihin, joilla ilmennetään tietynlaista helsinkiläistä identiteettiä tai osoitetaan tietoisuus tällaisesta syntyperäiseen ja aitoon helsinkiläisyyteen liittyvästä ominaisuudesta (vrt. Ainiala-Lappalainen 2010). Stadi esiintyy aineistossamme usein muiden slangisanojen kanssa, ja tässä ero Hesaan on suuri; tämä liittyy siihen, että slangisanojen ja -nimien katsotaan ilmentävän eräänlaista aitoa helsinkiläisyyttä (vrt. esim. Ainiala 2013). Hesa puolestaan tuntuu esiintyvän enemmän yleispuhekielisemmässä ympäristössä.

Tutkimuksemme nosti esiin uutena havaintona slanginimien vahvan liittymisen liikkumisen ja matkustamisen diskursseihin. Erityisen voimakkaasti tämä diskurssi liittyy Hesaan: tämän paljastavat liikkumista ja matkustamista merkitsevät kollokaatit, mutta lisäksi sekä paikkoja että ihmisiäkin koskevat kollokaatit vahvistavat tämän diskurssin läpileikkaavuutta aineistossa. Myös Stadiin liittyy liikkuminen, mutta näkökulma on selvästi erilainen: liikkuminen tapahtuu pikemmin Stadissa eli Helsingissä kuin Helsinkiin tai Helsingistä.

Melko leimallisesti aineistosta nousee esiin myös se, että Stadia käytetään, kun puhutaan "meistä stadilaisista" ja katsotaan kaupunkia sisältäpäin, kun taas Hesasta puhutaan 
kaupunkia ulkopuolelta katsoen. Nämä diskurssikäytänteet liittyvät usein juuri liikkumiseen ja matkustamiseen: Hesa tuntuu olevan ulkopaikkakuntalaisille matkustamisen kohde, kun tullaan erilaisiin tapahtumiin, tai välietappi ulkomaille matkustettaessa. "Stadilaisuutta" vahvistavat myös Stadin ulkopuolella asuviin kohdistuvat affektit, joita ilmaistaan melko pejoratiivisillakin "maalaisiin" kohdistuvilla nimityksillä.

Korpusavusteisen diskurssitutkimuksen avulla onnistuimme nostamaan esiin Hesan ja Stadin käytön ja niihin kytkettyjen merkitysten eroja ja yhtäläisyyksiä. Menetelmä nostaa esiin toistuvia piirteitä, joita ei ole tähän mennessä havaittu samoissa määrin haastattelu-, kyselylomake- ja keskusteluanalyysin menetelmin. Osittain tämä johtuu siitä, että Suomi24-keskustelupalstan kirjoittajat tulevat ympäri maata, joten keskustelu heijastaa ainakin jossain määrin kattavasti eri puolella Suomea esiintyviä diskursseja. Lisäksi spontaanisti kirjoitetut keskustelupuheenvuorot kertovat niin sanotusti aidoista käyttötavoista, eikä merkityksiä tai käyttötapoja ole tarvinnut tutkia memoroidun tai instrospektiivisen aineiston avulla. Toisaalta isoa datamäärää tilastollisesti analysoitaessa monet sinänsä merkittävät puhumisen tavat jäävät huomaamatta; menetelmä nostaa esiin sen, mitä on runsaasti. Käyttämällä laadullista analyysia kvantitatiivisen rinnalla voidaan päästä kiinni pienempiinkin nyansseihin; tässäkin tutkimuksessa laadullinen analyysi paljastaa eroja siellä, missä määrällisiä eroja ei juuri ole, tai se tarkentaa määrällistä analyysia. On kuitenkin ilman muuta selvää, että täsmentämällä ja syventämällä laadullista analyysia voitaisiin slanginimien käyttöä tarkastella monisyisemmin.

Nimistöntutkimuksen kannalta korpusonomastinen tutkimusote antaa uusia mahdollisuuksia laajojen tekstiaineistojen ja niissä käytettyjen nimien analyysiin. Huomattavaa on vielä sekin, että nimistöntutkimuksessa on tähän mennessä tartuttu vain harvoin ylipäänsä erilaisissa teksteissä - kaunokirjallisia tekstejä lukuun ottamatta - esiintyviin nimiin ja niiden kontekstuaaliseen analyysiin.

Käsillä oleva tutkimus on siis avaus paikannimien tutkimukseen korpusmenetelmin ja -aineistoin. Kahden slanginimen analyysilla olemme päässeet vain raapaisemaan paikannimitutkimuksen pintaa: Yhtä lailla mielenkiintoista olisi verrata slanginimien käyttöä Helsinki-nimeen tai tarkastella kaupunginosadiskursseja. Lisäksi on erittäin tähdellistä tarkastella sitä, ovatko tässä tutkimuksessa havaitut diskurssit tyypillisiä myös muille kaupunkinimille. Kun kurkotamme pääkaupungin ulkopuolelle, avautuu tutkimaton kenttä diskursseja, jotka liittyvät suomalaisiin kasvukeskuksiin ja syrjäkyliin.

\section{Lähteet}

Ainiala, Terhi 2013: Stadi and Hesa: Helsinki slang names as commercial names. Paula Sjöblom, Terhi Ainiala ja Ulla Hakala (toim.): Names and cultures in a commercial environment, 173184. Cambridge Scholars Publishing, Cambridge.

Ainiala, Terhi - Lappalainen, Hanna 2010: Miten Helsingistä puhutaan. Virittäjä 114 (1), 71-107.

2017: Orienting to norms: variability in the use of names for Helsinki. TerHi AINIALA ja JANOla Östman (toim.): Socio-onomastics. The pragmatics of names, 129-153. John Benjamins, Amsterdam. https://doi.org/10.1075/pbns.275.06ain 
Aller Media Oy 2014: Suomi 24 -korpus (2016H2) [tekstikorpus]. Kielipankki. Saatavilla http://urn.fi/ urn:nbn:fi:lb-2017021506

BAKer, PAUL 2006: Using corpora in discourse analysis. Continuum, London.

BARnBrook, Geoff 1996: Language and computers. A practical introduction to the computer analysis of language. Edinburgh University Press, Edinburgh.

BJORGE, ANNE KARI 2003: The explicitation of proper names in expository news texts. International Journal of Applied Linguistics 13 (1), 115-138. https://doi.org/10.1111/1473-4192.00040

Dalen-OsKam, Karina 2013: Names in novels: An experiment in computational stylistics. Literary and Linguistic Computing 28 (2), 359-370. https://doi.org/10.1093/llc/fqsoo7

Halverson Sandra L. - Engene, Jan Oska 2010: Domains and Dimensions in Metonymy: A Corpus-Based Study of Schengen and Maastricht. Metaphor and Symbol 25 (1), 1-18. https://doi. org/10.1080/10926480903538456

Hoey, MiCHAEL 2005: Lexical priming. A new theory of words and language. Routledge, London.

HÄMÄLÄINEN, LASSE 2019: Nimet verkossa. Tutkimus verkkoyhteisöjen käyttäjänimistä ja virtuaalisen minigolfpelin radannimistä. Helsingin yliopisto. Saatavilla http://hdl.handle.net/10138/301762

Ikkala, Esko - Tuominen, Jouni - RaunamaA, JaAkko - Aalto, Tiina - Ainiala, Terhi - Uusitalo, Helinä - Hyvönen, Eero 2018: NameSampo: A linked open data infrastructure and workbench for toponomastic research. Bruno Martins ja Patricia Murrieta-Flores (toim.): Proceedings of the 2nd ACM SIGSPATIAL Workshop on Geospatial Humanities, GeoHumanities 18, 2:1-2:9. https://doi.org/10.1145/3282933.3282936

Jantunen, JaRmo H. 2004: Synonymia ja käännössuomi. Korpusnäkökulma samamerkityksisyyden kontekstuaalisuuteen ja käännöskielen leksikaalisiin erityispiirteisiin. Joensuun yliopiston humanistinen tiedekunta, Joensuu.

2009: Minulla on aivan paljon rahaa - Fraseologiset yksiköt suomen kielen opetuksessa. Virittäjä 113 (3), 356-381.

2018: Korpusavusteinen diskurssintutkimus (CADS): Analyysiesimerkki homouden ja heterouden digitaalisista diskursseista. AFinLA-E: Soveltavan kielitieteen tutkimuksia (11), 20-44. https://doi.org/10.3066o/afinla.69259

KamandulytE, LAURA 2006: Identity analysis based on the methodology of corpus linguistics. Vytautas Magnus University, Kaunas. Saatavilla https://vb.vdu.lt/object/elaba:6142206/6142206.pdf

Kiviniemi, Eero 2006: Suomalaisten etunimet. Suomalaisen Kirjallisuuden Seura, Helsinki.

Lappalainen, Hanna 2006: Mie vai mää, sinä vai te? Virkailijoiden kielelliset valinnat itseen ja vastaanottajaan viitattaessa. MARJA-LeEna Sorjonen ja LiISA RaEvaARa (toim.): Arjen asiointia. Keskusteluja Kelan tiskin äärellä, 241-284. Suomalaisen Kirjallisuuden Seura, Helsinki.

LAPPE, SABINE 2002: Monosyllabicity in prosodic morphology: The case of truncated personal names in English. G. E. Booij ja JAAP VAN MARLe (toim.): Yearbook of Morphology 2002, 135-186. Springer Netherlands, Heidelberg. https://doi.org/10.1007/0-306-48223-1

LEINO, ANTTI 2007: On toponymic constructions as an alternative to naming patterns in describing Finnish lake names. Finnish Literature Society, Helsinki.

Meta-Share 2016. The Suomi24 Corpus. Saatavilla http://metashare.csc.fi/repository/browse/ the-suomi-24-corpus-2015h1/4db73da85ce11e4912c005056be118ea699d93902fa49d69bof 4 die692 dd $5 \mathrm{f}_{1} / 2$

Mikkonen, Pirjo - Paikkala, Sirkka 2000: Sukunimet. Otava, Helsinki.

Neuvonen, Jenni 2016: Sporalla stadilaiset skujaa. Joukkoliikennevälineiden slanginimitykset. Pro gradu -tutkielma, Helsingin yliopisto. Saatavilla http://urn.fi/URN:NBN:fi:hulib-201603071257

Nurminen, Terhi Johanna 2013: Hill-terms in the place-names of Northumberland and County Durham. University of Newcastle Upon Tyne, Newcastle.

Ohlander, Solve - Bergh, Gunnar 2004: Taliban-A rogue word in present-day English grammar. English Studies 85 (3), 206-229. https://doi.org/10.1080/00138380412331339120

Pagan, Joseph Martin 1998: A morphological and lexical study of personal names in the Ebla texts. Missione archeologica Italiana in Siria, Siria.

Partington, Alan - Duguid, Alison - Taylor, Charlotte 2013: Patterns and meanings in discourse. 
Theory and practice in corpus-assisted discourse studies (CADS). John Benjamins, Amsterdam. https://doi.org/10.1075/scl.55

Paunonen, Heikki - Paunonen, Marjatta 2000: Tsennaaks Stadii, bonjaaks slangii. Stadin slangin suursanakirja. WSOY, Helsinki.

Pierini, Patrizia 2008: Opening a Pandora's box: Proper names in English phraseology. Linguistik Online $36(4), 43-58$.

RAEVAARA, LiISA 2015: Hyvä päivä olla minä, mä ja meitsi - minän vaihtelevat asemat ja identiteetit helsinkiläisnuorten puheessa. Marja-Leena Sorjonen, Anu Rouhikoski ja Heini Lehtonen (toim.): Helsingissä puhuttavat suomet. Kielen indeksisyys ja sosiaaliset identiteetit, 174-213. Suomalaisen Kirjallisuuden Seura, Helsinki.

Scotт, Miкe 2015: WordSmith Tools online manual. Lexical Analysis Software, Stroud, Gloucestershire. Saatavilla https://lexically.net/downloads/version6/wordsmith6.pdf

Sinclair, John 1991: Corpus, concordance, collocation. Oxford University Press, Oxford.

2004: Trust the text. Language, corpus and discourse. Routledge, London.

Stubis, Mike 2001. Words and phrases. Corpus studies of lexical semantics. Blackwell, Oxford.

TANaka, Yu 2016: Phonotactically-Driven Rendaku in Surnames: A Linguistic Study Using Social Media. Aaron Kaplan, Abby Kaplan, Miranda K. McCarvel ja Edward J. Rubin (toim.): Proceedings of the 34th West Coast conference on formal linguistics, 519-528. Cascadilla Proceedings Project, Somerville.

Tse, Grace Y. W. 2004: A grammatical study of personal names in present-day English: With special reference to the usage of the definite article. English Studies 85 (3), 241-259. https://doi.org/10.1 080/00138380412331339140

Tuñón, Laura CANTORa 2013: Proper names as cultural referents in British chick lit : a corpus-based analysis of their translations into Spanish and Italian. The University of Leeds, Leeds. Saatavilla http://etheses.whiterose.ac.uk/7870/1/Proper\%20Names\%20as\%20Cultural\%2oReferents\%20 in\%2oBritish\%2oChick\%2oLit\%2o-\%2oLaura\%2oCantora.pdf

VAIČENONIENĖ, JÜRATĖ 2001: Using corpora to obtain social and cultural information: A case study of America. Kalbu Studijos / Studies about Language 1, 6-9.

\section{Terhi Ainiala and Jarmo Harri Jantunen: Corpus-onomastic study of slang names Hesa and Stadi in digital discourses}

The article discusses the uses of two slang names for the capital of Finland, Helsinki: Hesa and Stadi. In previous studies, these names have been under qualitative scrutiny, but our study takes a quantitative approach with a large corpus and statistical methodology. In onomastics, this kind of a corpus-assisted approach is a new way of examining the subject.

Our research data comes from the Suomi24 Corpus which contains discussions of the Suomi24 online social networking website, the largest discussion forum in Finland. The study is conducted as corpus-assisted discourse analysis. The first part of the study utilises collocation analysis, and in the second part, 200 most significant collocations from both slang names are examined more closely by classifying them into semantic classes. These semantic classes make up special discourse prosodies noticeable on phraseological grounds and they reveal how Hesa and Stadi are used in these digital discourses and what kind discourses they are associated with. 
The analysis reveals that slang names Hesa and Stadi both share common discourses and also have their own discourses. The name Hesa is used when Helsinki is looked at from an outside perspective or when it is seen as a destination or resort. Thus, discussions on various places, moving and travelling are typical to Hesa. In turn, Stadi is connected to the native and "original" Helsinkian identity. Stadi is used while talking about "us Helsinkians" and when the city is looked at from the inside. This kind of identity is presented even with using slang words together with Stadi or using the affective designations of non-native Helsinkians.

Terhi Ainiala

terhi.ainiala@helsinki.fi

Suomalais-ugrilainen ja pohjoismainen osasto

00014 Helsingin yliopisto
Jarmo Harri Jantunen

jarmo.h.jantunen@jyu.fi

Kieli- ja viestintätieteiden laitos 40014 Jyväskylän yliopisto 